Key words: academic culture, academic integrity, violation academic integrity plagiarism, psychological factors of plagiarism, moral values, development of creativity.

УДК 159.922:356.13(043.3)

Н. В. ВОЛИНЕЦЬ

DOI: https://doi.org/10.35619/prap_rv.vi12.43

\title{
ПОРІВНЯЛЬНИЙ АНАЛІЗ ОСОБЛИВОСТЕЙ ОСОБИСТІСНОГО БЛАГОПОЛУЧЧЯ ПРИКОРДОННИКІВ ТА ФАХІВЦІВ ІНШИХ ПРОФЕСІЙНИХ СПІЛЬНОТ В ЗАЛЕЖНОСТІ ВІД СТАЖУ РОБОТИ
}

У статті представлено результати порівняльного аналізу особливостей особистісного благополуччя персоналу Державної прикордонної служби України та психологів, соціальних працівників і сочіальних педагогів в залежності від стажу роботи. Виявлено, що переважна більшість прикордонників, психологів, соиіальних працівників та соиіальних педагогів мають середній з тендениією до високого рівень особистісного благополуччя, і щзо рівень особистісного благополуччя прикордонників є вищим порівняно з представниками інших професійних спільнот. Показано, щьо від стажу роботи залежать професійна компетентність і самореалізація, професійний розвиток і досягнення, загальний показник особистісного благополуччя прикордонників, а також професійна компетентність і самореалізащія психологів, соиіальних прачівників та сойіальних педагогів.

Ключові слова: особистісне благополуччя, особистісна самоефективність та гармонія, професійна компетентність та самореалізаџія, професійно-організаиійна мотивація, професійний розвиток і досягнення.

В статье представлены результаты сравнительного анализа особенностей личностного благополучия персонала Государственной пограничной службы Украины, психологов, сочиальных работников и сочиальных педагогов в зависимости от стажа работы. Выявлено, что подавляющее большинство пограничников, психологов, сочиальных работников и соииальных педагогов имеют средний с тенденцией к высокому уровень личностного благополучия, и уровень личностного благополучия пограничников выше по сравнению с представителями других профессиональных сообществ. Показано, что от стажа работь зависят профессиональная компетентность $и$ самореализация, профессиональное развитие и достижения, общий показатель личностного благополучия пограничников, а также профессиональная компетентность и самореализация психологов, сочиальных работников и сочиальных педагогов.

Ключевые слова: личностное благополучие, личностная самоэффективность и гармония, профессиональная компетентность и самореализачия, профессионально-организаџионная мотивачия, профессиональное развитие и достижения.

Постановка проблеми. Професійна сфера життєдіяльності особистості являється платформою становлення і формування цінностей, інтересів, установок, мотивів, які визначають спрямованість оцінок життедіяльності, знаходження власного місця в системі різних відносин, самоставлення, систему смислових утворень, що певною мірою детермінують ії особистісне благополуччя [1]. Особистісне благополуччя є суб'єктивним, оскільки погляди думки, відчуття та почуття працівників відображують зазначене переживання; в середовищі професійної діяльності воно переживається в процесі безпосереднього виконання роботи в певному організованому просторі, в якому відбувається професійна діяльність, і включає оцінки ними як самого середовища, в якому вона здійснюється, так і оцінку інших сфер життєдіяльності, в яких вони функціонують. Окрім того, особистісне благополуччя в професійній сфері життєдіяльності переживається в контексті особистісних спроможностей працівників здійснювати діяльність, а, отже, в контексті професійно важливих особистісних властивостей і можливостей їхньої реалізації в різних умовах. Отже, специфіка та досвід професійної діяльності певною мірою впливають і на переживання особистісного благополуччя. У зв’язку із зазначеним цікавим вбачається проведення порівняльного аналізу переживання особистісного благополуччя на різних етапах професіоналізації представниками тих професійних спільнот, які самі керують власним повсякденним та професійним життям, його розвитком, змінами, результатами тощо та представниками тих професійних спільнот, професійна діяльність яких суворо регламентується.

Аналіз останніх досліджень і публікацій. Особистісне благополуччя вивчається науковцями у взаємозв'язку з кар'єрними орієнтаціями (О. Бондарчук) [2], 3 професійною адаптацією та Випуск 12, 2019. Збірник наукових праць РДГУ 
професійними деструкціями (С. Дружилов) [3], зі ставленням до грошей у людей різних професійних груп (А. Злотковська, О. Титова) [4], з наявністю обмежених можливостей здоров'я (А. Лєбєдєва) [5], з саморегуляцією (Ю. Олександров) [6], з різною специфікою трудової діяльності (Т. Федотова) [7], 3 осмисленістю життя (П. Фесенко) [8], з різним профілем часової перспективи (Г. Хафізова) [9], 3 екстремальними умовами життєдіяльності (О. Ширяєва) [10] та ін.

Формулювання цілей статті. Представлення результатів порівняльного аналізу особливостей особистісного благополуччя персоналу Державної прикордонної служби України та психологів, соціальних працівників і соціальних педагогів в залежності від стажу роботи.

Виклад основного матеріалу дослідження. 3 метою виявлення рівнів та типів особистісного благополуччя було використано розроблений скринінг-опитувальник особистісного благополуччя призначений для експрес-діагностики рівнів переживання (високого, середнього з тенденцією до високого, середнього $з$ тенденцією до низького та низького) та типів переживання особистісного благополуччя (особистісно-орієнтованого, кар'єрно-орієнтованого, професіонально-орієнтованого та соціально-орієнтованого). Концептуальною основою скринінг-опитувальника стала структурна модель особистісного благополуччя в середовищі професійної діяльності, відповідно до якої особистісне благополуччя розглядається як складне комплексне психологічне утворення, що містить структурні компоненти особистісної здійсненності, особистісної самоефективності, особистісної гармонії, професійної компетентності та самореалізації, професійно-організаційної мотивації та професійного розвитку й досягнень та розроблена на іiї основі типологія особистісного благополуччя. Для виявлення особливостей особистісного благополуччя від стажу використано методи математикостатистичних даних: розрахунки середнього арифметичного та стандартного відхилення для визначення міри центральної тенденції та мінливості досліджуваних показників, Н-критерію Краскала-Уоллеса для виявлення відмінностей у досліджуваних показниках особистісного благополуччя в залежності від стажу роботи.

У емпіричному дослідженні особистісного благополуччя прийняли участь: 1) експериментальна група: 302 військовослужбовці-прикордонники, з них: 203 особи - слухачі курсів перекваліфікації (з них 183 особи - чоловіки, 20 осіб - жінки), 99 осіб - офіцери - слухачі факультету підготовки керівних кадрів (чоловіки), віком від 23 до 55 років, зі стажем служби в ДПС України від 1 до 26 років. У вибірці представлено респондентів з усіх регіональних управлінь ДПС України; 2) контрольна група: 82 психологи, соціальні працівники та соціальні педагоги Київської, Луганської, Львівської, Харківської, Херсонської та Хмельницької областей, з них: 65 жінок та 17 чоловіків, 34 особи, які мають досвід приватної професійної практики та 48 осіб, які не мають досвіду приватної професійної практики, віком 23-68 років, зі стажем роботи 1-49 років. За результатами тестування виявлено відмінності у наступних показниках особистісного благополуччя прикордонників та психологів, соціальних працівників і соціальних педагогів в залежності від стажу роботи:

1) За показником особистісної здійсненності життя у всіх групах досліджуваних з різним стажем роботи виявлено найбільшу кількість осіб з високим та середнім з тенденцією до високого рівнями. Цим особам притаманні відповідні рівні емоційної чутливості до себе і до світу, гармонійності у ставленні до себе та здатності відчувати себе і світ, рівні внутрішнього переживання і співчуття, здатності насолоджуватися життям, здатності керувати зовнішнім світом, готовності приймати активну участь у власному житті та вибудовувати його, рівні почуття обов'язку та відповідальності, автентичності та незалежності, цілеспрямованої орієнтації на майбутнє, потреби у цікавій стабільній роботі, наповненості життя можливостями та перспективами. За результатами розрахунків середнього арифметичного та стандартного відхилення особистісної здійсненності життя в залежності від стажу роботи виявлено: а) в контрольній групі: у всіх досліджуваних переважає середній з тенденцією до високого рівень цього показника, проте найвищі його значення виявлено у групах досліджуваних зі стажем роботи більше 30 років $\left(\mathrm{M}_{\text {сер }} \pm \mathrm{m}=66.75 \pm 2.375, \sigma=8.226\right)$, які позитивно оцінюють процес та результати прожитого життя, реалізовані цілі та здобутки, а також зі стажем роботи 6-10 років $\left(\mathrm{M}_{\text {сер }} \pm \mathrm{m}=65.00 \pm 4.318, \sigma=13.654\right)$, які знаходяться на тому етапі життя, коли набули достатнього досвіду для здійснення професійної діяльності, створили сім'ю, народили дітей, мають достатній рівень фізичного та психічного здоров'я для якісного життя, формують цілі та досягають їх, мають перспективи на майбутнє тощо. Найменше середнє значення та найбільш мінливе значення показника особистісної здійсненності життя виявлено у групі досліджуваних зі стажем роботи 21-30 років $\left(\mathrm{M}_{\text {сер }} \pm \mathrm{m}=58.74 \pm 4.107, \sigma=17.904\right)$, що може бути пов'язано 3 кризою середнього віку; б) в експериментальній групі: у всіх досліджуваних переважає середній з тенденцією до високого рівень цього показника, проте найвищі його значення виявлено у прикордонників зі стажем роботи 6-10 років $\left(\mathrm{M}_{\text {сер }} \pm \mathrm{m}=66.51 \pm 1.046, \sigma=10.246\right), 11-20$ років $\quad\left(\mathrm{M}_{\text {сер }} \pm \mathrm{m}=66.48 \pm 0.906\right.$, $\sigma=10.092)$ та $21-30$ років $\left(\mathrm{M}_{\text {сер }} \pm \mathrm{m}=66.66 \pm 1.774, \sigma=10.034\right)$, які позитивно оцінюють процес та 
результати прожитого життя, реалізовані цілі та здобутки. Найменше середнє значення та найбільш мінливе значення показника особистісної здійсненності життя виявлено у прикордонників зі стажем роботи 6-10 років $\left(\mathrm{M}_{\text {сер }} \pm \mathrm{m}=64.64 \pm 1.664, \sigma=11.768\right)$, що може бути пов’язано з меншим життєвим та професійним досвідом порівняно з іншими групами.

2) За показником особистісної самоефективності у всіх групах досліджуваних з різним стажем роботи виявлено найбільшу кількість осіб з високим та середнім з тенденцією до високого рівнями. Цим особам притаманні відповідні рівні ефективності самоуправління та особистісного зростання у контексті співвіднесення власних професійних досягнень із досягненнями колег, самоповаги, самовпевненості та впевненості у власній професійній компетентності, вмілості, досвідченості; переважання внутрішньої узгодженості професійного самоставлення, прояву потреб у досягненнях і регулярному менеджменті в управлінні. За результатами розрахунків середнього арифметичного та стандартного відхилення особистісної самоефективності в залежності від стажу роботи виявлено: а) в контрольній групі: у всіх досліджуваних переважає середній з тенденцією до високого рівень цього показника. Найвище середнє значення цього показника виявлено у групі досліджуваних зі стажем роботи більше 30 років $\left(\mathrm{M}_{\mathrm{cep}} \pm \mathrm{m}=49.17 \pm 1.804, \sigma=6.250\right)$, які позитивно оцінюють сформовані особистісні якості, вкладені зусилля, набуті досягнення та їх роль у власному житті. Найменше середнє значення та найбільш мінливе значення показника особистісної самоефективності виявлено у групі досліджуваних зі стажем роботи 0-5 років $\left(\mathrm{M}_{\text {сер }} \pm \mathrm{m}=42.53 \pm 1.609, \sigma=6.232\right)$, які тільки почали самостійне доросле життя і не мають достатньо досягнень в особистісному та професійному житті, щоб дуже високо оцінювати власну ефективність, а також зі стажем роботи 21-30 років $\left(\mathrm{M}_{\mathrm{cep}} \pm \mathrm{m}=42.84 \pm 2.892, \sigma=12.606\right)$, що може бути пов'язано 3 кризою середнього віку; б) в експериментальній групі: у всіх досліджуваних переважає високий рівень особистісної самоефективності. Найвищі значення цього показника виявлено у групі досліджуваних зі стажем роботи 21-30 років $\left(\mathrm{M}_{\mathrm{cep}} \pm \mathrm{m}=60.22 \pm 1.228, \sigma=6.946\right)$, а найнижчий - зі стажем роботи 0-5 років $\left(\mathrm{M}_{\mathrm{cep}} \pm \mathrm{m}=57.20 \pm 1.359, \sigma=9.613\right)$.

3) За показником особистісної гармонії у всіх групах досліджуваних з різним стажем роботи виявлено найбільшу кількість осіб з високим та середнім $з$ тенденцією до високого рівнями. Цим особам притаманні відповідні рівні задоволеністю повсякденною діяльністю, самопочуття та стану здоров'я, позитивності впливу роботи та незалежність від інших осіб; задоволеності умовами праці та досягненнями в роботі, товариськості та дружелюбності; відповідні рівні прагнення реалізовувати особистісні цінності, таланти і досвід для досягнення певної суспільно важливої мети; прагнення до інтеграції різних стилів життя та втілення в роботі власних ідеалів і цінностей. За результатами розрахунків середнього арифметичного та стандартного відхилення особистісної гармонії в залежності від стажу роботи виявлено: а) в контрольній групі: у всіх досліджуваних переважає середній з тенденцією до високого рівень цього показника, проте найвищі його значення виявлено у досліджуваних зі стажем роботи більше 30 років $\left(\mathrm{M}_{\text {сер }} \pm \mathrm{m}=51.58 \pm 2.076, \sigma=7.192\right)$, які більше задоволені повсякденною та професійною діяльністю, мають позитивний настрій та оптимістично налаштовані на майбутне. Найменше середнє значення та найбільш мінливе значення показника особистісної гармонії виявлено у групі досліджуваних зі стажем роботи 21-30 років $\left(\mathrm{M}_{\mathrm{cep}} \pm \mathrm{m}=38.53 \pm 2.603, \sigma=11.345\right)$, що може бути пов'язано 3 кризою середнього віку; б) в експериментальній групі: у всіх досліджуваних переважає середній з тенденцією до високого рівень особистісної гармонії. Найвищі його значення виявлено у досліджуваних зі стажем роботи 11-20 років $\left(\mathrm{M}_{\mathrm{cep}} \pm \mathrm{m}=42.15 \pm 0.879, \sigma=9.784\right)$ та 21-30 років $\left(\mathrm{M}_{\mathrm{cep}} \pm \mathrm{m}=42.88 \pm 1.263, \sigma=7.147\right)$, які найбільше задоволені повсякденною та професійною діяльністю, мають позитивний настрій та оптимістично налаштовані на майбутнє. Найменше середнє значення та найбільш мінливе значення показника особистісної гармонії виявлено у прикордонників зі стажем роботи $0-5$ років $\left(\mathrm{M}_{\mathrm{cep}} \pm \mathrm{m}=40.02 \pm 1.551\right.$, $\sigma=10.968)$, що може бути пов'язано з малим життєвим та професійним досвідом життя.

4) За показником професійної компетентності та самореалізації у всіх групах досліджуваних 3 різним стажем роботи виявлено найбільшу кількість осіб з високим та середнім з тенденцією до високого рівнями. Ці особи мають відповідні рівні інтересу до роботи, професійної затребуваності, компетентності, авторитету та оцінки позитивності ставлення до них 3 боку інших людей, приналежності до професійної спільноти, оцінки результатів професійної діяльності та задоволеності реалізацією професійного потенціалу, взаєминами з керівництвом, прагнення працювати у команді та орієнтації на інтеграцію зусиль колег, підлеглих для виконання професійних задач. За результатами розрахунків середнього арифметичного та стандартного відхилення професійної компетентності та самореалізації в залежності від стажу роботи виявлено: а) в контрольній групі: у всіх досліджуваних переважає середній з тенденцією до високого рівень цього показника, окрім групи досліджуваних зі стажем роботи більше 30 років, в якій виявлено найвищі його значення (високий рівень середнього 
значення) $\quad\left(\mathrm{M}_{\text {сер }} \pm \mathrm{m}=65.25 \pm 1.966, \sigma=6.811\right)$, оскільки вони більш професійно затребувані та компетентні, мають авторитет серед колег, високо оцінюють результати власної професійної діяльності, найбільше задоволені реалізацією професійного потенціалу порівняно з іншими групами. Найменше середне значення показника професійної компетентності та самореалізації виявлено у групі досліджуваних зі стажем роботи 0-5 років $\left(\mathrm{M}_{\text {сер }} \pm \mathrm{m}=51.73 \pm 1.640, \sigma=6.352\right)$, що пов'язано 3 недостатнім строком здійснення професійної діяльності для набуття професійного досвіду, професійної компетентності, авторитету серед колег тощо; б) в експериментальній групі: у всіх досліджуваних переважає середній з тенденцією до низького рівень професійної компетентності та самореалізації. Найвище середнє значення цього показника виявлено у групі досліджуваних зі стажем роботи 21-30 років $\left(\mathrm{M}_{\text {сер }} \pm \mathrm{m}=44.59 \pm 1.273, \sigma=7.202\right)$, оскільки вони більш професійно затребувані та компетентні, мають авторитет серед колег, високо оцінюють результати власної професійної діяльності, найбільше задоволені реалізацією професійного потенціалу порівняно з іншими групами, a найнижчий - зі стажем роботи 0-5 років ( $\left.\mathrm{M}_{\text {сер }} \pm \mathrm{m}=41.62 \pm 1.539, \sigma=10.883\right)$, що пов'язано 3 недостатнім строком здійснення професійної діяльності для набуття професійного досвіду, професійної компетентності, авторитету серед колег тощо.

5) За показником професійно-організаційної мотивації у всіх групах досліджуваних з різним стажем роботи виявлено найбільшу кількість осіб з високим та середнім з тенденцією до високого рівнями. Ці особи мають відповідні рівні самоуправління повсякденним та професійним життям, прийняття рішень та їхньої реалізації; інтересу до власного життя, його емоційної насиченості та наповненості смислом; задоволеності самореалізацією, продуктивності і осмисленості прожитого життя; задоволеності власним прожитим життям, позитивності споминів про минуле, задоволеності теперішнім життям та спрямованості на майбутнє; самодостатності, прояву потреб у винагороді, у креативності та в умовах праці; орієнтації на досягнення успіху, на співпрацю, на збереження цілісності організації та позитивну мотивацію. За результатами розрахунків середнього арифметичного та стандартного відхилення професійно-організаційної мотивації в залежності від стажу роботи виявлено: а) в контрольній групі: у всіх досліджуваних переважає середній 3 тенденцією до високого рівень цього показника, проте найвищі його середні значення та найменш мінливі виявлено у досліджуваних зі стажем роботи більше 30 років $\left(\mathrm{M}_{\text {сер }} \pm \mathrm{m}=66.75 \pm 2.111, \sigma=7.313\right)$. Найменше середне значення показника професійно-організаційної мотивації виявлено у досліджуваних зі стажем роботи $21-30$ років $\left(\mathrm{M}_{\text {сер }} \pm \mathrm{m}=62.42 \pm 3.118, \sigma=6.352\right)$, що пов'язано 3 переживанням кризи середнього віку, невпевненістю у власній спроможності керувати повсякденним та професійним життям, незадоволеністю прожитим життям, життям в теперішньому; наявністю сумнівів у своїй здатності щось змінити або зробити та схильністю до самоприниження та самозвинувачення у невдачах; б) в експериментальній групі: у всіх досліджуваних переважає середній $з$ тенденцією до високого рівень професійно-організаційної мотивації. Найвище середнє значення цього показника виявлено у групі досліджуваних зі стажем роботи 21-30 років $\left(\mathrm{M}_{\mathrm{cep}} \pm \mathrm{m}=66.13 \pm 1.118, \sigma=6.323\right)$, що пов'язано з усвідомленням прикордонниками, що їхнє професійне життя наближається до закінчення, і вони, не маючи інших сфер професійної самореалізації, окрім служби в прикордонному відомстві, мають високу мотивацію залишитися на ній якомога довше. Найменше середнє значення показника професійно-організаційної мотивації виявлено у прикордонників зі стажем роботи 6-10 років $\left(\mathrm{M}_{\text {сер }} \pm \mathrm{m}=63.80 \pm 0.987, \sigma=9.671\right)$, що бути пов'язано 3 невідповідністю очікувань, пов'язаних із виконанням професійних функцій, можливостями кар'єрного просування, отриманням винагороди потребам прикордонників; зниженням ентузіазму і завзятості при виконанні службових дій; неможливістю досягнення поставлених в минулому цілей; зниженням інтересу до виконуваних завдань.

6) За показником професійного розвитку та досягнень у всіх групах досліджуваних з різним стажем роботи виявлено найбільшу кількість осіб з високим та середнім 3 тенденцією до високого рівнями. Ці особи мають відповідні рівні професійного розвитку, автономності, задоволеності рівнем компетентності та професійними досягненнями, позитивними відносинами в колективі; визначеності професійних цілей, прояву потреб у взаємостосунках та у визнанні, здатності до ретроспективної, ситуативної та перспективної рефлексії. За результатами розрахунків середнього арифметичного та стандартного відхилення професійного розвитку та досягнень в залежності від стажу роботи виявлено: а) в контрольній групі: у всіх досліджуваних переважає середній з тенденцією до високого рівень цього показника. Найвищі його середні значення та найменш мінливі виявлено у групах досліджуваних зі стажем роботи 6-10 років $\left(\mathrm{M}_{\mathrm{cep}} \pm \mathrm{m}=58.10 \pm 2.100, \sigma=6.641\right)$, які набули достатнього професійного досвіду для оцінки власного професійного зростання та досягнень порівняно з періодом первинної професіоналізації, та у досліджуваних зі стажем роботи більше 30 років $\left(\mathrm{M}_{\mathrm{cep}} \pm \mathrm{m}=58.08 \pm 1.952, \sigma=6.762\right)$, які вільно володіють професією у формі майстерності, керують 
професійною діяльності та професійним розвитком та мають високі професійні здобутки. Найменше середне значення та найбільш мінливе значення показника професійного розвитку та досягнень виявлено у досліджуваних зі стажем роботи 0-5 років $\left(\mathrm{M}_{\text {сер }} \pm \mathrm{m}=49.00 \pm 3.369, \sigma=13.049\right)$, що пов'язано 3 переживаннями, пов'язаними із засвоєнням професійної ролі, недостанім досвідом самостійного виконання професійної діяльності та набуттям професійно важливих якостей; б) в експериментальній групі: у всіх досліджуваних переважає середній з тенденцією до високого рівень професійного розвитку та досягнень. Найвище середнє значення цього показника виявлено у групі досліджуваних зі стажем роботи $21-30$ років $\left(\mathrm{M}_{\text {сер }} \pm \mathrm{m}=58.94 \pm 1.256, \sigma=7.107\right)$, що пов'язано 3 майстерністю у професійній діяльності, управлінням професійним розвитком та високими професійними здобутками. Найменше середнє та найбільш мінливе значення цього показника виявлено у прикордонників зі стажем роботи 0-5 років $\left(\mathrm{M}_{\text {сер }} \pm \mathrm{m}=55.62 \pm 1.168, \sigma=8.258\right)$, що бути пов'язано 3 початком їхнього професійного життя, недостатнім професійним розвитком та незначними професійними досягненнями.

За результатами розрахунків середнього арифметичного та стандартного відхилення загального показника особистісного благополуччя в залежності від стажу роботи виявлено: а) в контрольній групі: у всіх досліджуваних переважає середній з тенденцією до високого рівень цього показника, проте найвищі його середні значення виявлено у досліджуваних зі стажем роботи 6-10 років $\left(\mathrm{M}_{\mathrm{cep}} \pm \mathrm{m}=336.70 \pm 13.501, \sigma=42.693\right)$ та у групі досліджуваних зі стажем роботи більше 30 років $\left(\mathrm{M}_{\mathrm{cep}} \pm \mathrm{m}=349.25 \pm 13.775, \sigma=47.719\right)$. Найменше середнє найбільш мінливе значення загального показника особистісного благополуччя виявлено у досліджуваних зі стажем роботи 21-30 років $\left(\mathrm{M}_{\mathrm{cep}} \pm \mathrm{m}=314.05 \pm 18.560, \sigma=80.903\right)$, що пов'язано 3 переживанням кризи середнього віку; б) в експериментальній групі: у всіх досліджуваних переважає середній з тенденцією до високого рівень особистісного благополуччя. Найвище середнє та найменш мінливе значення цього показника виявлено у досліджуваних зі стажем роботи $21-30$ років $\left(\mathrm{M}_{\text {сер }} \pm \mathrm{m}=337.97 \pm 5.837, \sigma=33.021\right)$, що пов'язано 3 тим, що у прикордонників з таким стажем $є$ вищими усі показники особистісного благополуччя порівняно з іншими групами. Найменше середнє та найбільш мінливе значення цього показника виявлено у прикордонників зі стажем роботи 0-5 років $\left(\mathrm{M}_{\text {сер }} \pm \mathrm{m}=323.38 \pm 4.857, \sigma=34.346\right)$, що пов'язано 3 початком періоду активної життєдіяльності та професійного життя, нижчими показниками особистісної здійсненності життя, особистісної самоефективності та гармонії, професійної компетентності та самореалізації, професійного розвитку та досягнень.

У переважної більшості прикордонників, психологів, соціальних працівників та соціальних педагогів виявлено особистісно-орієнтований тип особистісного благополуччя. Найбільшу кількість осіб з особистісно-орієнтованим типом особистісного благополуччя виявлено в контрольній групі у досліджуваних зі стажем роботи більше 30 років (у 11 (91.67\%) осіб) та зі стажем роботи 6-10 років (у 9 (90.00\%) осіб); в експериментальній групі - у досліджуваних зі стажем роботи 11-20 років (у 78 (62.90\%) осіб). Вони переживають благополуччя в контексті як особистісної здійсненності власного життя. Це особи з почуттям вільного власного вибору (свободи), які знаходять реальні можливості дії в будь-яких ситуаціях, приймають персонально обгрунтовані рішення; мають чіткі уявлення про себе як про сильну особистість, здатну вибудовувати власне життя відповідно до своїх цілей і уявлень про його сенс. Вони готові до самореалізації та приймають активну участь у власному житті, отримують задоволення від взаємин з керівництвом та колегами, проявляють інтерес до роботи, позитивно ставляться до себе як до фахівців, які можуть реалізувати свій професійний потенціал, мають виражене диференційоване уявлення про себе як представників професійної спільноти і, в зв'язку 3 цим, сформоване позитивне емоційне самоставлення та ставлення до цінностей професійної спільноти, з якою себе ідентифікують.

Найбільшу кількість осіб з професіонально-орієнтованим типом особистісного благополуччя виявлено у досліджуваних зі стажем роботи $0-5$ років (у 4 (26.67 \%) осіб) та зі стажем роботи 11-20 років (у 5 (19.23\%) осіб) в контрольній групі та у досліджуваних зі стажем роботи 0-5 років (у 14 $(28.00 \%)$ осіб) в експериментальній групі. Вони переживають благополуччя процес самореалізації як професіонала, і мають чіткі уявлення про власну спроможність вибудовувати життя у відповідності 3 власними цілями та уявленнями про його смисл; несуть відповідальність за себе і своє життя, спроможні доводити до кінця рішення, прийняті на підставі особистих цінностей з усвідомленням обов'язковості цього для себе або зобов'язань перед іншими людьми.

Кар'єрно-орієнтований тип особистісного благополуччя виявлено в контрольній групі: зі стажем роботи 0-5 років у 2 (13.33 \%) осіб, зі стажем роботи $11-20$ років у 2 (7.69 \%) осіб та зі стажем роботи 21-30 років у 3 (15.79\%) осіб; в експериментальній групі: зі стажем роботи 0-5 років у 5 $(10.00 \%)$ осіб, зі стажем роботи 6-10 років у $9(9.38 \%)$ осіб, зі стажем роботи $11-20$ років у 13 (10.48 $\%)$ осіб та зі стажем роботи 21-30 років у 4 (12.50\%) осіб. Вони переживають особистісне 
благополуччя як результат успіхів в кар'єрі за умови володіння владними повноваженнями, що дають можливість для прийняття ключових рішень та управління людьми, проектами тощо зі значними делегованими повноваженнями і мають яскраво виражену потребу у цікавій роботі та орієнтовані на іiі стабільність 3 мінімальною ймовірністю звільнення.

Соціально-орієнтований тип особистісного благополуччя виявлено: в контрольній групі: зі стажем роботи 0-5 років у $13,3 \%$ осіб, зі стажем роботи $11-20$ років у $3,9 \%$ та зі стажем роботи $21-30$ років у $5,3 \%$ особ; в експериментальній групі: стажем роботи $0-5$ років у $6 \%$ осіб, зі стажем роботи 6-10 років 9,4\% осіб, зі стажем роботи 11-20 років у 6,5\% осіб та зі стажем роботи 21-30 років у 12,5 $\%$. Вони переживають особистісне благополуччя в контексті соціальних взаємодій, реалізують власний інтерес до роботи та отримують задоволення від взаємин з керівництвом та іншими людьми; переживають задоволення потреби у досягненнях; задоволені умовами праці; у них переважає хороший настрій та оптимістичне сприйняття майбутнього. Вони отримують задоволення від атмосфери згуртованої єдності, що дає можливість працювати в «общинній» спільноті, яка формується на взаємних симпатіях, групових інтересах, групових нормах поведінки, і орієнтована на мотивування до здійснення професійної діяльності, а також у задоволенні потреб у винагороді, в умовах праці та в креативності, а також мають яскраво виражену потребу у формуванні та підтримці довгострокових стабільних взаємостосунків при значній близькості взаємин, які базуються на довірі.

Виявлено також змішані типи особистісного благополуччя, які містять характеристики двох відповідних типів благополуччя, що може бути пов'язано з їхнім прагненням реалізуватися в декількох сферах життєдіяльності: в контрольній групі: в контрольній групі - зі стажем роботи 0-5 років: професіонально-кар'єрно-орієнтований тип - у 13,4 \% респондентів; зі стажем роботи 11-20 років: професіонально-соціально-орієнтований тип - у 3,9 \% осіб; зі стажем роботи 21-30 років: професіонально-кар'єрно-орієнтований тип - у 5,3 \%) особи, особистісно-соціально-орієнтований тип - у 5,3 \% осіб, особистісно-професіонально-оріснтований тип - у 5,3 \% учасників, в експериментальній групі: професіонально-кар'єрно-орієнтований тип - у досліджуваних зі стажем роботи $0-5$ років у $4.0 \%$ респондентів, зі стажем роботи $6-10$ років у $3,1 \%$ осіб та зі стажем роботи 11-20 років у 0,8 \%учасників.

3 метою виявлення відмінностей у досліджуваних показниках особистісного благополуччя в залежності від стажу роботи було проведено розрахунки Н-критерію Краскала-Уоллеса, за результатами яких виявлено: в контрольній групі статистично значущі відмінності особистісної гармонії $\left(\chi^{2}=14,705\right.$; при $\left.\mathrm{p}=0.005\right)$, професійної компетентності та самореалізації $\left(\chi^{2}=15,382\right.$, при $\mathrm{p}=0.004)$, професійного розвитку та досягнень $\left(\chi^{2}=9.187\right.$, при $\left.\mathrm{p}=0,050\right)$ та типу благополуччя $\left(\chi^{2}=\right.$ $15,111$; при $\mathrm{p}=0,004)$ психологів, соціальних працівників та соціальних педагогів залежно від стажу роботи. Такі показники як особистісна здійсненність життя, особистісна самоефективність, професійно-організаційна мотивація та загальний показник особистісного благополуччя в контрольній групі не мають відмінностей в залежності від стажу роботи. В експериментальній групі виявлено статистично значущі відмінності професійної компетентності та самореалізації $\left(\chi^{2}=8,958\right.$, при $\mathrm{p}=0,041)$, професійного розвитку та досягнень $\left(\chi^{2}=9.383\right.$, при $\left.\mathrm{p}=0.023\right)$ та загального показника особистісного благополуччя $\left(\chi^{2}=10,226\right.$, при $\left.\mathrm{p}=0.038\right)$ прикордонників від стажу роботи. Такі показники як особистісна здійсненність життя, особистісна самоефективність та гармонія, професійно-організаційна мотивація та тип особистісного благополуччя в експериментальній групі не мають відмінностей в залежності від стажу роботи. За результатами кореляційного аналізу виявлено пряму кореляційну залежність показника професійної компетентності й самореалізації $\left(\mathrm{r}_{\mathrm{s}}=0,347\right.$, при $\mathrm{p}=0,001)$ психологів, соціальних працівників та соціальних педагогів від стажу роботи на рівні високої статистичної значущості; та пряму кореляційну залежність професійної компетентності й самореалізації $\left(\mathrm{r}_{\mathrm{s}}=0,279\right.$, при $\left.\mathrm{p}=0.042\right)$, професійного розвитку та досягнень $\left(\mathrm{r}_{\mathrm{s}}=0,280\right.$ при $\left.\mathrm{p}=0,043\right)$ та загального показника особистісного благополуччя $\left(\mathrm{r}_{\mathrm{s}}=0,312\right.$, при $\left.\mathrm{p}=0,050\right)$ прикордонників від стажу роботи на рівні статистичної значущості.

Висновки та перспективи подальших досліджень. Переважна більшість прикордонників, психологів, соціальних працівників та соціальних педагогів мають середній з тенденцією до високого рівень особистісного благополуччя. Найвищі середні значення показників особистісного благополуччя виявлено у прикордонників зі стажем роботи 21-30 років та у психологів, соціальних працівників і соціальних педагогів зі стажем роботи більше 30 років, які позитивно оцінюють власні сформовані особистісні якості, процес та результати прожитого життя, реалізовані цілі, вкладені зусилля, набуті досягнення, задоволені повсякденною та професійною діяльністю, мають позитивний настрій та оптимістично налаштовані на майбутнє, професійно затребувані та компетентні, мають авторитет серед колег, високо оцінюють результати власної професійної діяльності, найбільше задоволені реалізацією професійного потенціалу, вільно володіють професією у формі майстерності,

Випуск 12, 2019 Збірник наукових праць РДГУ. 
керують професійним розвитком та мають високі професійні здобутки, а також у групі психологів, соціальних працівників та соціальних педагогів зі стажем роботи 6-10 років, які знаходяться на такому етапі життя, коли набули достатнього досвіду для здійснення професійної діяльності, створили сім'ю, народили дітей, мають достатній рівень фізичного та психічного здоров'я для якісного життя, формують цілі та досягають їх, мають перспективи на майбутнє, набули достатнього професійного досвіду для оцінки власного професійного зростання та досягнень порівняно з періодом первинної професіоналізації.

Найнижчі середні значення показників особистісного благополуччя виявлено у прикордонників зі стажем роботи 0-5 років та у психологів, соціальних працівників і соціальних педагогів зі стажем роботи 0-5 років, які тільки почали самостійне доросле життя і не мають достатньо досягнень в особистісному та професійному житті, щоб дуже високо оцінювати власну ефективність, що пов’язано з недостатнім строком здійснення професійної діяльності для набуття професійного досвіду, професійної компетентності, авторитету серед колег, недостатнім професійним розвитком та досягненнями, що пов'язано із засвоєнням професійної ролі, недостанім досвідом самостійного виконання професійної діяльності та набуттям професійно важливих якостей, а також у психологів, соціальних працівників та соціальних педагогів зі стажем роботи 21-30 років, що може бути пов'язано з переживанням кризи середнього віку. У переважної більшості прикордонників, психологів, соціальних працівників та соціальних педагогів виявлено особистісно-орієнтований тип благополуччя. Серед прикордонників виявлено значно більше осіб з професіонально-орієнтованим та кар'єро-орієнтованим типами особистісного благополуччя, що свідчить про більшу орієнтацію прикордонників на набуття високого рівня професіоналізму та прагнення будувати кар'єру у прикордонному відомстві порівняно з психологами, соціальними працівниками та соціальними педагогами.

Професійна компетентність і самореалізація, професійний розвиток і досягнення, загальний показник особистісного благополуччя прикордонників прямо пропорційно залежать від стажу роботи на рівні статистичної значущості, а професійна компетентність і самореалізація психологів, соціальних працівників та соціальних педагогів прямо пропорційно залежить від стажу роботи на рівні високої статистичної значущості. Перспективи подальших розвідок пов’язані з виявленням особливостей особистісного благополуччя різних професійних спільнот в залежності від специфіки професійної діяльності.

\section{Список використаних джерел}

1. Шамионов Р. М. Субъективное благополучие личности в профессиональной среде / P. М. Шамионов // Проблемы в социальной психологии личности. - Саратов, 2008. - URL : http://psyjournals.ru/sgu_socialpsy/issue/30341_full.shtml.

2. Бондарчук О. І. Кар'єрні орієнтації керівників освітніх організацій як чинник їх суб'єктивного благополуччя / О. І. Бондарчук // Вісник післядипломної освіти : зб. наук. пр. / НАПН України, Ун-т менедж. освіти ; гол. ред. : В. В. Олійник ; редкол. : О. Л. Ануфрієва [та ін.]. - Київ : АТОПОЛ ГРУП, 2016. - Вип. 2 (31). - С. 18-28. - (Серія «Соціальні та поведінкові науки»).

3. Дружилов С. А. Профессиональное благополучие человека и психологические аспекты профессиональной адаптации и профессиональных деструкций / С. А. Дружилов // Современные научные исследования и инновации. - 2016. - № 12. - URL : http://web.snauka.ru/issues/2016/12/76347.

4. Злотковская А. В. Взаимосвязь психологического благополучия и отношения к деньгам у людей разных профессиональных групп / А. В. Злотковская, О. И. Титова // Молодёжь Сибири науке России : материалы Междунар. науч.-практ. конф., г. Красноярск, 24-25 апр. 2014 г. Красноярск, 2014. - C. 137-139. - URL : http://www.sibup.ru/attachments/article/662/sbornik_molodezh_ 2014.pdf.

5. Лебедева А. А. Субъективное благополучие лиц с ограниченными возможностями здоровья : автореф. дис. ... канд. психол. наук : 19.00.01 / А. А. Лебедева. - М., 2012. - 32 с.

6. Олександров Ю. М. Саморегуляція як чинник психологічного благополуччя студентської молоді : дис. ... канд. психол. наук : 19.00.01 / Ю. М. Олександров ; Харк. нац. ун-т ім. В. Н. Каразіна. - Харків, 2010. - 296 с.

7. Федотова Т. Особливості вияву суб’єктивного благополуччя як показника психічного здоров'я особистості (на прикладі працівників державної служби) / Т. Федотова // Psychological Prospects Journal. - 2018. - Вип. 31. - С. 280-291. - DOI : https://doi.org/10.29038/2227-1376-2018-31280-291.

8. Фесенко П. П. Осмысленность жизни и психологическое благополучие личности : автореф. дис. ... канд. психол. наук : 19.00.01 / П. П. Фесенко. - М., 2005. - 24 с. 
9. Хафізова Г. С. Особливості психологічного благополуччя у людей з різним профілем часової перспективи / Г. С. Хафізова // Вісник Харківського національного університету імені В. Н. Каразіна. Серія : Психологія. - 2013. - № 1065, вип. 52. - C.51-54. - URL: http://nbuv.gov.ua/UJRN/VKhIPC_2013_1065_52_12.

10. Ширяева О.С. Психологическое благополучие личности в экстремальных условиях жизнедеятельности : дис. ... канд. психол. наук : 19.00.01 / О. С. Ширяева. - ПетропавловскКамчатский, 2008. - 254 с.

\section{References}

1. Shamionov R. M. Sub\#ektivnoe blagopoluchie lichnosti v professional'noj srede / R. M. Shamionov // Problemy v social'noj psihologii lichnosti. - Saratov, 2008. - URL : http://psyjournals.ru/sgu_socialpsy/issue/30341_full.shtml.

2. Bondarchuk O. I. Kar'yerni oriyentaciyi kerivny`kiv osvitnix organizacij yak chy`nny`k yix sub'yekty`vnogo blagopoluchchya / O. I. Bondarchuk // Visny`k pislyady`plomnoyi osvity` : zb. nauk. pr. / NAPN Ukrayiny`, Un-t menedzh. osvity`; golov. red. V. V. Olijny`k ; redkol. : O. L. Anufriyeva [ta in.]. Kyiv : ATOPOL GRUP, 2016. - Vy`p. 2 (31). - S. 18-28. - (Seriya «Social`ni ta povedinkovi nauky`»).

3. Druzhilov S. A. Professional'noe blagopoluchie cheloveka i psihologicheskie aspekty professional'noj adaptacii i professional'nyh destrukcij / S. A. Druzhilov // Sovremennye nauchnye issledovanija i innovacii. - 2016. - № 12. - URL : http://web.snauka.ru/issues/2016/12/76347.

4. Zlotkovskaja A. V. Vzaimosvjaz' psihologicheskogo blagopoluchija i otnoshenija k den'gam u ljudej raznyh professional'nyh grupp / A. V. Zlotkovskaja, O. I. Titova // Molodjozh' Sibiri - nauke Rossii : materialy Mezhdunar. nauc.-prakt. konf., g. Krasnojarsk, 24-25 apr. 2014 g. - Krasnojarsk, 2014. - S. 137139. - URL : http://www.sibup.ru/attachments/article/662/sbornik_molodezh_2014.pdf.

5. Lebedeva A. A. Sub\#ektivnoe blagopoluchie lic s ogranichennymi vozmozhnostjami zdorov'ja : avtoref. dis. ... kand. psihol. nauk : 19.00.01 / A. A. Lebedeva. - M., 2012. - $32 \mathrm{~s}$.

6. Oleksandrov Yu. M. Samoregulyaciya yak chy`nny`k psy`xologichnogo blagopoluchchya students`koyi molodi : dis. ... kand. psihol. nauk : 19.00.01 / Yu. M. Oleksandrov ; Xark. nac. un-t im. V. N. Karazina. - Xarkiv, 2010. - 296 s.

7. Fedotova T. Osobly`vosti vy`yavu sub'yekty`vnogo blagopoluchchya yak pokazny`ka psy`xichnogo zdorov'ya osoby`stosti (na pry`kladi pracivny`kiv derzhavnoyi sluzhby`) / T. Fedotova // Psychological Prospects Journal. - 2018. - Vy`p. 31. - S. 280-291. - DOI : https://doi.org/10.29038/22271376-2018-31-280-291.

8. Fesenko P. P. Osmyslennost' zhizni i psihologicheskoe blagopoluchie lichnosti : avtoref. dis. ... kand. psihol. nauk : 19.00.01 / P. P. Fesenko. - M., 2005. - 24 s.

9. Xafizova G. S. Osobly`vosti psy`xologichnogo blagopoluchchya u lyudej z rizny`m profilem chasovoyi perspekty`vy`/ G. S. Xafizova // Visny`k Xarkivs`kogo nacional`nogo universy`tetu imeni V. N. Karazina. Seriya : Psy`xologiya. - 2013. - № 1065, vy`p. 52. - S. 51-54. - URL: http://nbuv.gov.ua/UJRN/VKhIPC_2013_1065_52_12.

10. Shirjaeva O. S. Psihologicheskoe blagopoluchie lichnosti $\mathrm{v}$ jekstremal'nyh uslovijah zhiznedejatel'nosti : dis. ... kand. psihol. nauk : 19.00.01 / O. S. Shirjaeva. - Petropavlovsk-Kamchatskij, 2008. - $254 \mathrm{~s}$.

\section{N. V. Volynets COMPARATIVE ANALYSIS OF THE PECULIARITIES OF PERSONAL WELL-BEING OF BORDER GUARDS AND SPECIALISTS OF OTHER PROFESSIONAL GROUPS ON DEPENDING ON WORK EXPERIENCE}

In the article the results of the comparative analysis of the peculiarities of personal well-being of the staff of the State Border Guard Service of Ukraine and psychologists, social workers and social pedagogues on depending on their work experience are represented. It has been revealed that the vast majority of border guards, psychologists, social workers and social educators have an average tendency to a high level of personal well-being, and that the level of personal well-being of border guards is higher compared to those of other professional groups. The highest values of personal well-being indicators were revealed among border guards with work experience of 21-30 years and psychologists, social workers and social pedagogues with work experience of 6-10 years and more than 30 years. The lowest values of personal well-being indicators were revealed in border guards, psychologists, social workers and social pedagogues with work experience of 0-5 years. It is shown that professional competence and self-realization, professional development and achievements, a general indicator of personal well-being of border guards, as well as professional competence and self-realization of psychologists, social workers and social pedagogues depend on their work experience. 
Key words: personal well-being, personal self-efficacy and harmony, professional competence and self-realization, professional-organizational motivation, professional development and achievements

УДК 159.9-047.22:616-051:373.2

В. М. ВРОНСЬКА

DOI: https://doi.org/10.35619/prap_rv.vi12.44

\section{ОСОБЛИВОСТІ ПСИХОЛОГІЧНОЇ КОМПЕТЕНТНОСТІ МЕДИЧНОЇ СЕСТРИ ДОШКІЛЬНОГО НАВЧАЛЬНОГО ЗАКЛАДУ}

На даний час дуже актуальною є проблема збереження та зміцнення здоров'я дітей. Важливу роль при иьому відіграють медичні сестри дошкільних навчальних закладів (далі- ДНЗ). Їм недостатньо мати лише фахову підготовку, медичні сестри ДНЗ повинні мати сформовану психологічну компетентність (відповідно до характеру роботи у даному закладі). Автором проаналізовано особливості вимог до діяльності медичної сестри, починаючи від запровадження иієі професії $і$ до сучасних вимог до діяльності медичної сестри дошкільного навчального закладу зокрема.

Ключові слова: здоров'я, медичні сестри дошкільних навчальних закладів, компетентність, комунікація, робота з вихованцями, робота з батьками, психологічна компетентність.

В это время очень актуальной есть проблема сохранения и укрепления здоровья детей. Важную роль при этом играют медиииские сестры дошкольных учебных заведений (дальше - ДУЗ). Им недостаточно иметь только специальную підготовку, медицинские сестры ДУЗ должны кметь сформированную психологическую компетентность (в соответствии с особенностями работы в данном заведении). Автором проанализировань особенности тренований $\kappa$ деятельности медицинской сестры, начиная от зарождения этой профессии и до современных тренований к деятельности медицинской сестры ДУЗ в часности.

Ключевые слова: здоровъе, медиинские сестры дошкольных учебных заведений, компетентность, коммуникаџия, работа с воспитанниками, работа с родителями; психологическая компетентность.

Постановка проблеми. Батьки в дошкільні навчальні заклади віддають найдорожче власних дітей. Тому, варто піклуватися про збереження та зміцнення здоров'я вихованців. Крім вихователів, це завдання вирішують медичні сестри ДНЗ, які повинні бути готові до роботи в освітніх закладах і мати не лише професійно важливі якості, а і сформовану психологічну компетентність. Тому, своїм завданням вбачаємо висвітлення особливостей психологічної компетентності медичних сестер дошкільних закладів, які позитивно впливають на ефективність виконання їхніх посадових обов’язків. Аналіз становлення уявлень про фахово-важливі якості медичної сестри ДНЗ.

Аналіз останніх досліджень і публікацій. Вчені враховують особливості та важливість надання медичної допомоги дітям. С.Ю.Кокотова акцентує увагу на тому, що психопрофілактичній і просвітницькій роботі з лікарями-педіатрами потрібно приділяти значну увагу, тоді їхнє ставлення до цієї роботи та участь в ній суттєво вплине на їі результат. «Зовнішнє професійне середовище вимагає надмірної емоційної напруженості при виконанні професійних обов'язків лікаря-педіатра, що у ракурсі постійного переживання стресової напруги може призвести до емоційного вигорання, певних мотиваційних викривлень» [3, с. 4]. На взаємозв'язок комунікативної взаємодії і мотивації медиків до виконання професійної діяльності вказував І. С. Сук і зазначав: «питання психологічної несумісності лікаря і хворого не допустиме» [7, с.48].

Однак питання підготовки медичних сестер, для освітніх закладів досі не привернуло належної уваги. Ціла низка спеціальних знань та умінь, потрібних для лікування й догляду за хворими в освітньому закладі не будуть затребуваними, але з іншого боку, набагато вищими стають вимоги іншого характеру. Зокрема, ширшим і детальнішим та набагато менш формалізованим є коло комунікативної взаємодії медичних сестри. До нього входять не лише діти, але й всі без винятку працівники закладу. Широта й різноманітність характеру фахового спілкування медичної сестри ДНЗ пояснюється таким чинником, як різноманітність їі фахових функцій, до яких входять не лише планові профілактичні заходи що стосуються саме дітей, але й низка дій щодо контролю за санітарним станом всього закладу та харчуванням дітей. Ефективне здійснення гігієнічноконтролюючих функції за роботою технічного персоналу та педагогічного колективу передбачає уміння подати свої вимоги у індивідуалізованій і не надто офіційній формі, а це у свою чергу

Випуск 12, 2019. Збірник наукових праць РДГУ 